\title{
Graphic study and geovisualization of the old windmills of La Mancha (Spain)
}

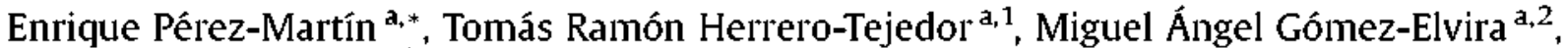 \\ José Ignacio Rojas-Sola ${ }^{\mathrm{b}, 3}$, Miguel Ángel Conejo-Martin ${ }^{\mathrm{a}, 1}$ \\ ${ }^{a}$ Techical University of Madrid (UPM), Department of Cartographic Engineeling, Geodesy, Photogrammetry - Graphic Expression, Ciudad Universitaria, 28040 Madrid, Spain \\ b University of Jaén. Department of Engineering Graphics, Design and Projects, Campus de las Lagunillas, s/n. 23071 jaén. Spain
}

Keywords:

Agro-industrial heritage

Virtual heritage

Digital reconstruction and 3D modelling

Windmill

CAD

Surveying

Photogrammetry

Cartography

\begin{abstract}
A B S T R A C T
In Spain, one can find geographical diversity and unique sites of great significance and cultural heritage. Many of the nation's treasured places, however, have deteriorated or have even disappeared. What is left, then, should be studied and documented both graphically and infographically. It is important to preserve and document Spain's unique locations, especially those related to vernacular heritage, to transhumance and visual impact assessment in many national infrastructures projects. Windmills are important examples of agro-industrial heritage and are sometimes found in the beds of streams and rivers but can also be found high in the hills. Their presence is constant throughout the Iberian Peninsula. These mills are no longer in use due to technological advances and the emergence of new grinding systems. The aim of this study was to present a specific methodology for the documentation of windmills, to create a graphical representation using computer graphics, as well as to disseminate knowledge of this agroindustrial heritage. This research has integrated graphic materials, including freehand sketches. photographs, digital orthophotos, computer graphics and multimedia in the creation of a specific methodology based on cutting-edge technology such as a digital photogrammetric workstation (DPW). global navigation satellite systems (GNSS). computer-aided design (CAD) and computer animations.
\end{abstract}

\section{Introduction}

According to [COMOS (International Council on Monuments and Sites) and ISPRS (International Society of Photogrammetry and Remote Sensing), a monument can be restored and protected only when it has been fully measured and documented. Currently, projects like 3D-COFORM, CARARE, EUROPEANA are establishing mechanisms to facilitate the documentation and disclosure of our cultural heritage in an accessible, practical and effective way. These are European Union projects that aim towards the long-term preservation of cultural heritage documentation.

This project of geovisualization includes a series of photographical, graphical, cartographical and infographical material, which comforms a specific GIS. In this aspect, we mention other examples of applied projects of geovisualization such as that of
Philadelphia GeoHistory Network (http:/Www.philageohistory. org) or UCLA Cultural Virtual Laboratory (http:/www.cvilab.org).

This article is the latest in a line of researches studying agroindustrial heritage. Some useful background studies on the elements of cultural heritage can be found in the references section of this paper (Arias, Ordonez, Lorenzo. Herraez, \& Armesto, 2007; Herrero, 2005 \& Pérez, 2008).

Close-range photogrammetry has been used in studies of the external representation of windmills (Arias, Ordóñez, Lorenzo, \& Herraez, 2006). Considering this earlier research, the present study focused specifically on creating a comprehensive methodology for the study of the cultural heritage of windmills in Spain.

The methodology and conclusions of our research are important to understanding and disseminating information about industrial archaeology and the history of technology as they relate to the agro-industrial heritage of windmills (Rojas-Sola \& AmezcuaOgayar, 2005 \& Rojas-Sola, Gómez-Elvira, \& Pérez, 2006). The aim was to obtain the principal technical parameters of Manchegan windmills, including the power and momentum obtained. These results will be discussed according to Betz's theory.

In this paper, we present solutions such as graphic and cartographic representation by integrating computer-aided design, surveying, photogrammetry, cartography and computer graphics. The metric accuracy is sufficient for producing a graphical 
representation of heritage restoration projects and for helping to improve cultural awareness.

According to the historical artistic description (regulation 63/ 2002) made when windmills were declared of Cultural Interest. they are constructions which witness the industrial activity in old times and the human struggle for controling the forces of nature exploiting its resources. Some of these landmark constructions, or their ruins, still remain reflecting this process of the industrial history.

The first bibliographic references show that the first windmill was created by Heron ( $20-62$ d.C.), and it was used for blowing the bellows of an organ. However, it is thought that the first windmills used for irrigation and milling appeared in Sijistan (Persia) in the VII century. They had an important function and rapidly spread throughout Europe and the Arab countries. In the beginning, there was a waterwheel but the milling by means of milling windmills was due to the need of taking advantage of other source of energy: the wind. In places likely subjected to drought where there were not strong watercourses, windmills were installed, which implied a further technical innovative variation, thus meaning a lower cost because it did not depend of the contingency of the water, the air did not assured a permanent activity neither (Aguilar, 1986; Cádiz \& Ramos, 1984).

Although windmills were different types of constructions, depending on the region, those from Castilla-La Mancha had the shape of a cylindrical tower, made of masonry, crowned by a conical cover, first made of straw and later on made of wood. The axe to which the blades made of poplar, holm oak or oak were fixed, peeped out through a type of porthole. Inside, these windmills were made up of three floors: the silo or ground floor, the place where millers used to leave the mules; the deckhouse or middle floor, where the grain was cleaned and some farm implements and tools were kept; and the milling room or machinery room, with some small windows for the entrance of the wind.

\section{Study area}

The study focuses on the windmills of Cerro Calderico in the town of Consuegra (Toledo, Spain) and in the Sierra de los Molinos y Cerro de la Paz in Campo de Criptana (Ciudad Real, Spain) (Fig. 1). We used the following criteria in selecting our study sites. First, the municipalities must be located in the region of Castilla-La Mancha, which has a long-standing tradition as a cereal mill area, (Mazuecos, 1971) and second, they must have been declared a historical site by the Spanish Historical Heritage (Fig. 2).

There are written references about the existence of windmills in La Mancha (Relaciones Topográficas, s. XVI); they are graphically recorded in some pictures and Spanish landscape views where we can recognise the existence of these windmills of La Mancha (Van den Wyngaerde, s. XVI). The windmills of La Mancha were introduced by mid XV century, being broadly spread in the XVI and XVII centuries. They began to decline by the end of the XIX century, although they were in service until mid XX century (Sánchez-Ruiz, 1995).

The protected buildings and other cultural properties should also enrich the knowledge of culture inherent in their creation or intangible cultural heritage (Veco, 2010).

Buildings meeting the above criteria are historic sites in accordance with Articles 11 and 16 of Law 16/1985 on Spanish Historical Heritage. A determination of a historic site may not be made without prior approval by the regional body with jurisdiction in the matter (the Historical Heritage Commission or, where appropriate, the Directorate General of Cultural Assets and Activities). This study provides a new methodology for the comprehensive study of cultural heritage, referring not only to the buildings present in a given location but also to the geographical area as a whole.

Fernández-Layos (1985) described one of the first engravings found from the eighteenth century in which the crest of Calderico hill is depicted. This was found as a result of the voyages of Don Juan José de Austria and was designed by Pier Maria Baldi. It depicts
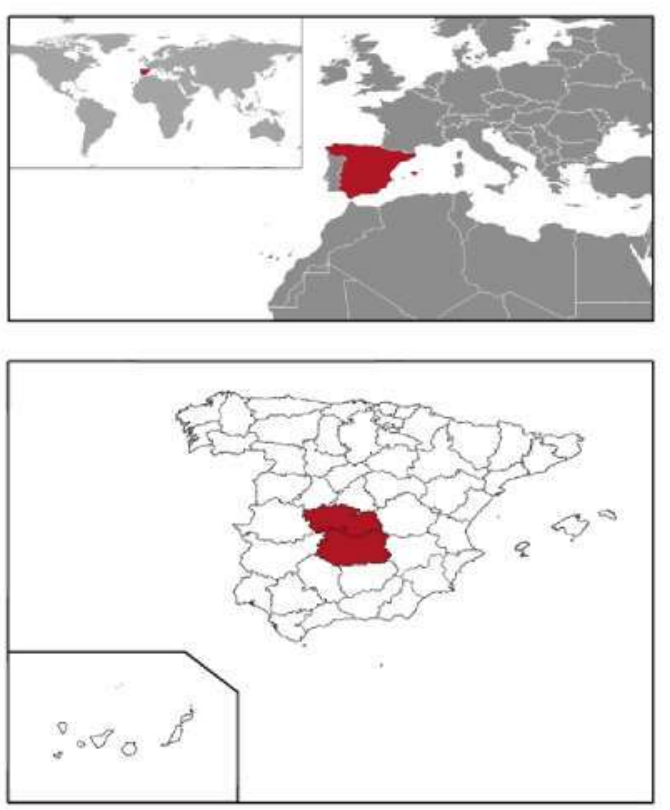

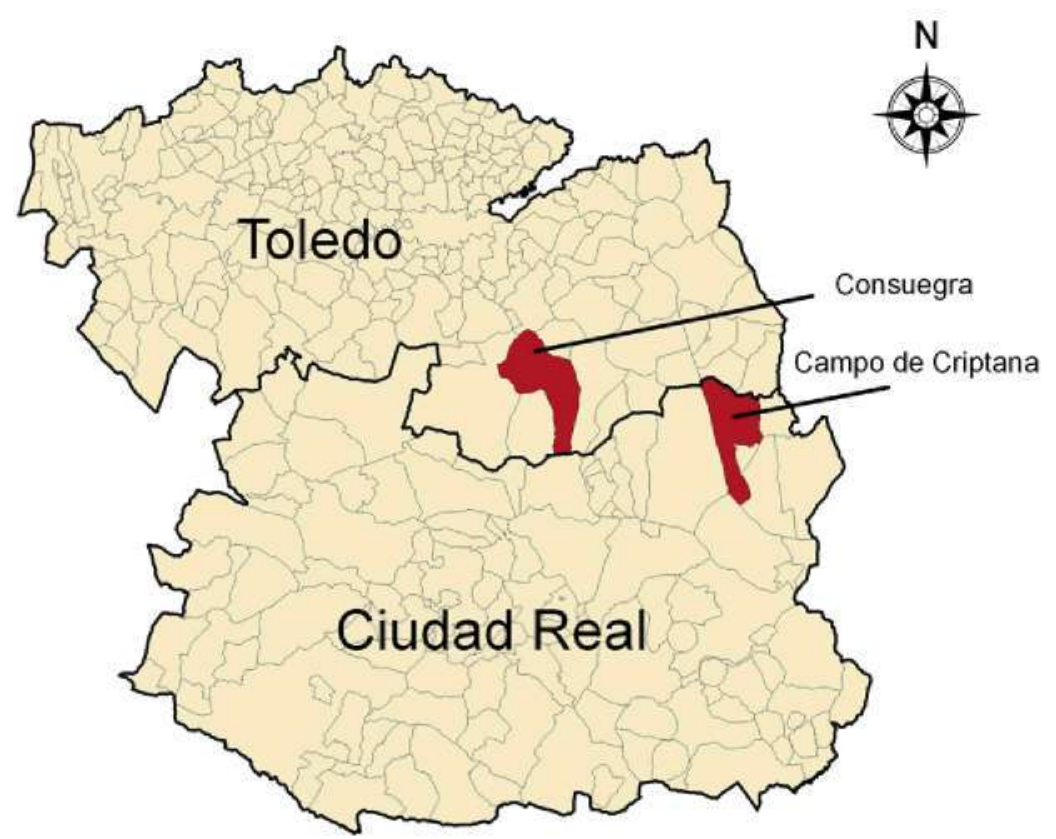
$25 \quad 50$ 100 150 200

Fig. 1. Location of Consuegra (Toledo) and Campo de Criptana (Ciudad Real). 
Spanish Historical Heritage

\begin{tabular}{|c|c|c|c|}
\hline Cultural Property & Ten Hill Calderico and Mills & Cultural Property & Windmills "Hill of Peace and Sierra de los Molinos" \\
\hline Region & C.A. Castilla-La Mancha & Region & C.A. Castilla-La Mancha \\
\hline Province & Toledo & Province & Ciudad Real \\
\hline municipality & Consuegra & municipality & Campo de Criptana \\
\hline category & Historic Site & category & Historic Site \\
\hline Code & (A.R.I. $-54-0000229-00000$ & Code & (R.I.) $-54-0000145-00000$ \\
\hline Register of Cultural Property & (A.R.I. & Register of Cultural Property & (R.I.) \\
\hline Opening date & $28 / 11 / 2006$ & Opening date & 09/07/2001 \\
\hline Bulletin Commencement Date & $12 / 01 / 2007$ & Bulletin Commencement Date & $03 / 05 / 2002$ \\
\hline Provision & RESOLUTION & Declaration Date & $11 / 10 / 2001$ \\
\hline \multirow[t]{3}{*}{ Note } & PROCESSED 6\%A & Bulletin Date Statement & $03 / 05 / 2002$ \\
\hline & & Provision & RESOLUTION \\
\hline & & Note & PROCESSED G:A \\
\hline
\end{tabular}

Fig. 2. Database of Spanish Historical Heritage. Ministry of Culture.

a bare Calderico hill with no windmills; the only structure shown on the hill is the old fort St John. Because the castle was used as a priory until the eighteenth century, it is likely that windmills were not allowed in this area (Jiménez, 2001). In the eighteenth century, some chronicles document the existence of two flour mills on the river Amarguillo. In 1847, these chronicles documented the existence of 10 windmills in Consuegra (Madoz, 1845), most of which were probably located on Calderico hill (Fig. 3).

At present, 11 of the 13 mills that once crowned the hill remain. The so-called "Sancho" mill maintains its sixteen century machinery in perfect condition and is used to mill wheat during a traditional feast that is held annually in the city, the Feast of the Rose of Saffron (on the last Sunday in October). The windmills found in Campo de Criptana overlook the Sierra de los Molinos y Cerro de la Paz. According to the "Catastro de Ensenada" (1749-1756), there were more than 30 windmills in the "Sierra de los Molinos" Criptana Field (Escribano, 2000). Of those, only ten remain.

We can appreciate the geographical distribution of windmills in Spain in a catalogue made by Caro Baroja (1952). In 1991, Sánchez

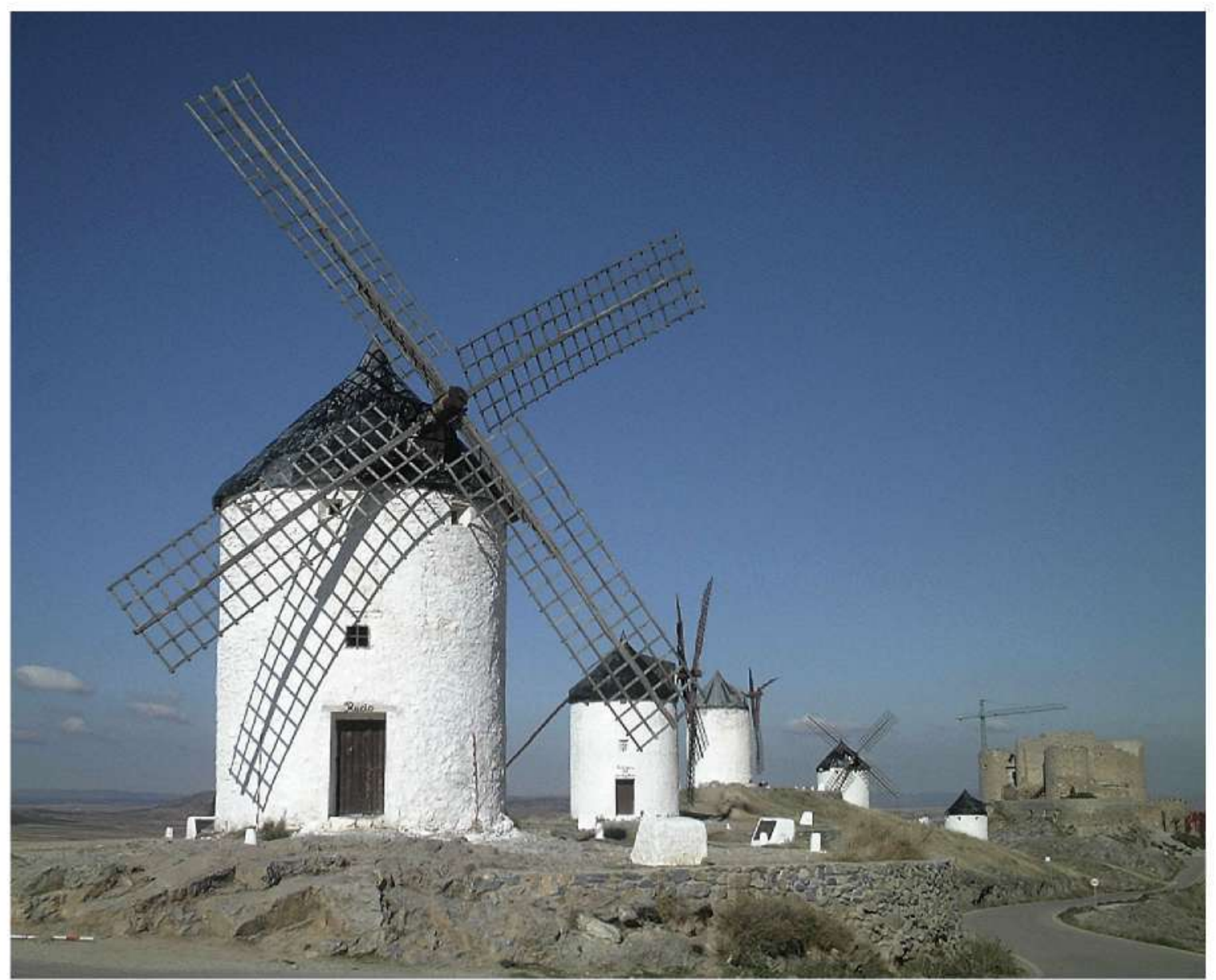

Fig. 3. Windmill at Calderico Hill (Consuegra). 
Molledo presents a new complete map of windmills in Castilla-La mancha but not complete enough for the rest of Spain. Fernández \& Fernândez (1997) gathers a lot of information about windmills in Spain and offers a cartographical representation (Fig. 4).

What is hereby written about the la Mancha windmills is essentially based upon their description and that of its machinery. not existing however a research from the graphical and cartographical representation perspective.

The aim of this study was to present a specific methodology for the documentation of windmills, their graphical representation and computer graphics, as well as to disseminate knowledge of this agro-industrial heritage by using artwork such as digital orthophotos, computer animation and multimedia.

\section{Methods}

The specific methodology used for reporting this agro-industrial heritage contains two sections corresponding to field work and the subsequent reconstruction graph (Fig. 5). It was necessary the help of a high-resolution DEM building for a complete study of windmills and the quality of the geovisualization. Considering this need a new line of research about the high-resolution DEM generation is opened (Pérez, Herrero, Gómez-Elvira, \& Rojas Sola, 2008).

\section{Photogrammetric process}

In recent years, the use of digital cartography, basic document management and spatial planning to update databases that handle geographic and other digital applications enables a rapid and effective response in projects territorial planning (Konecny, 2000). In this context, the generation and application of Digital Elevation Models (DEM) are used to create a three-dimensional representation of a surface (Martin, Llamas, Melero, Gomez-Garcia-Bermejo, \& Zalama, 2010). Generally, digital photogrammetry presents a number of advantages over other methods (McGlone, 2004).

We obtained the orthophotography of Calderico hill in Consuegra (Toledo) (Fig. 6).

\section{Topographic process}

We were able to determine the height of the windmill "Rucio" located on Calderico hill. The methodology used was as follows:

- We did a field study of visibility between stations and formed a closed polygon around the mill at each of the highest points of the roof. Three points were made into topographic stations: E1, E2 and E3 visible among them two by two (Fig. 7). The starting coordinates of the polygon were obtained using GNSS techniques.

- To calculate the height of the mill, we used a method known as direct intersection, with which we obtained the coordinates of an unknown point using points with known coordinates (Fig. 7). The height of the mill was $11.93 \mathrm{~m}$ from the floor to the top of the roof.

\section{Data collection process}

We gathered all of the necessary information to create a graphic representation of the machinery of a windmill in La Mancha. We

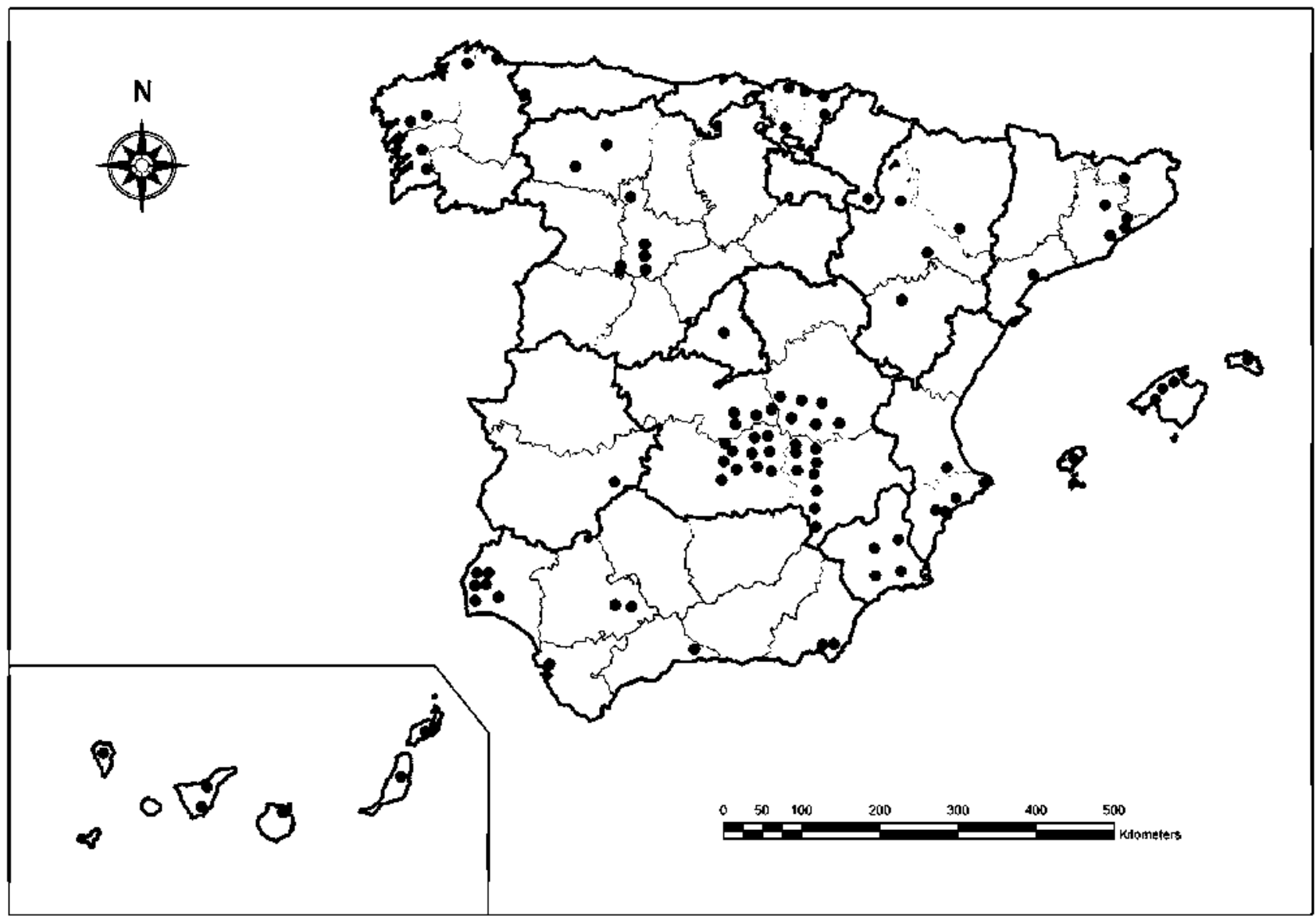

Fig. 4. Mapping of old mills in Spain. Fernández \& Felnández (1997). 


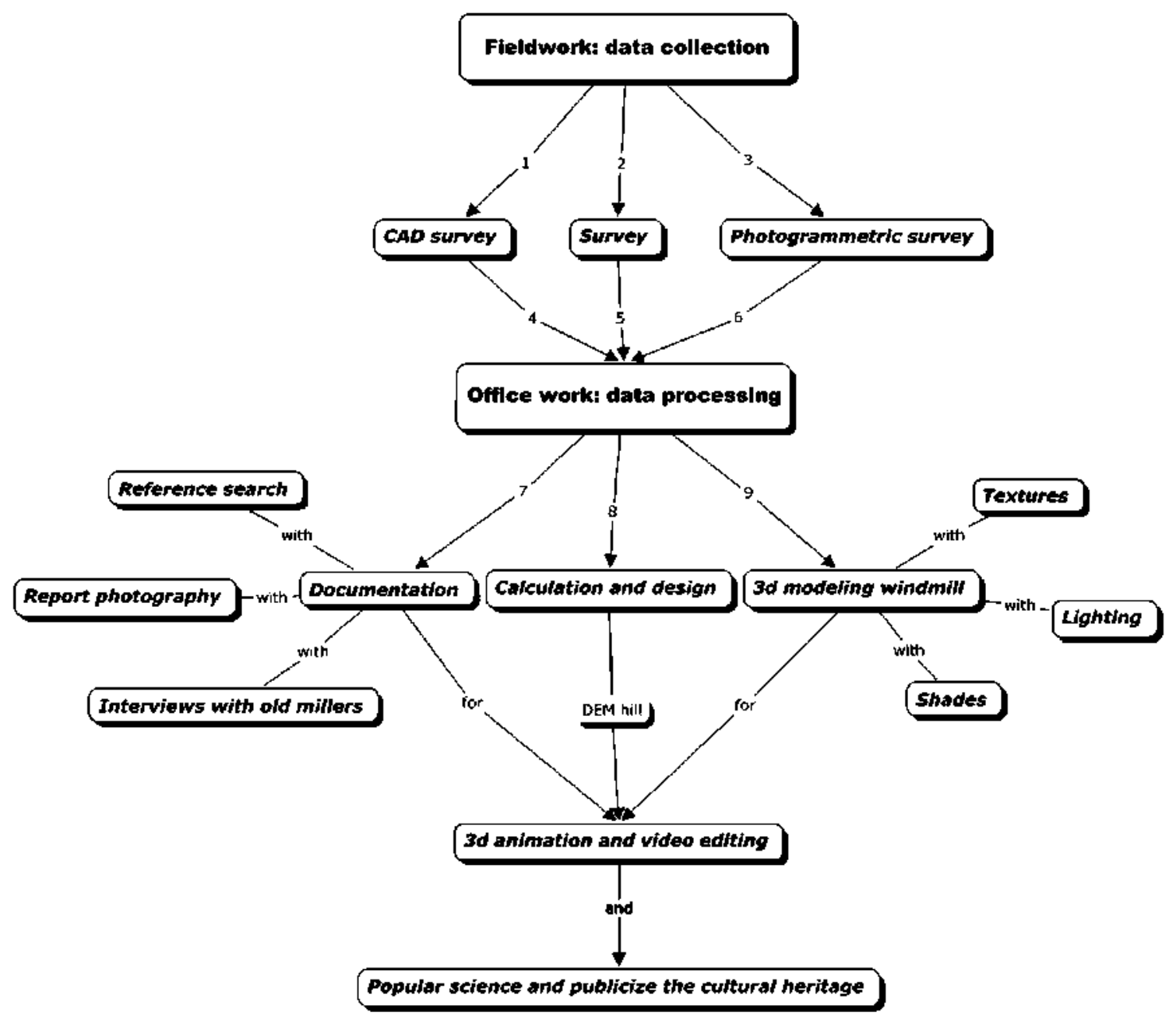

Fig. 5. Methodology employed.

conducted interviews of former millers to explain the operation of the mill and to describe how it may have worked in the past.

The mill under study is located on a hill and it is surrounded by the following elements:

- Milestones. They are whitewashed small stone markers. The number can be from 9 to 12 , protruding from the soil about $40 \mathrm{~cm}$ at a distance of $5.5 \mathrm{~m}$ from the mill. They are used to moor the "borriquillo".

- "Bortiquillo". It is a lathe, which mission is to move, through a string, a bar stick ("palo de gobjerno") to rotate the conical element of the windmill (approximately a weight of $5000 \mathrm{~kg}$ ). In order to know the direction and intensity of the wind, there are some portholes at the third floor of the windmill. The function of each porthole $(20 \times 30 \mathrm{~cm})$ is to collect the prevailing wind at all times.

For the correct location of the above items, meteorological data from the automatic station are used, No. 4-067 Madridejos $\left(03^{\circ} 32^{\prime} \mathrm{W}, 39^{\circ} 28^{\prime} \mathrm{N}\right)$

Based on studies of descriptions of the machinery of the windmill (Camuñas-Rosell, 2000), we obtained a series of sketch drawings (Fig. 8) and digital photos of the windmill "Infante" that showed the operating schematics of the windmills in La Mancha and allowed us to prepare a graphical reconstruction.

The graphic reconstruction was planned as follows:

\section{D modelling}

First, we created a schematic representation of a set of objects, elements and properties that, once processed (rendered), became alternatively a three-dimensional image or an animation of a real event.

Modelling was done before and after visits to the windmill. After the first visits, we updated the model based on new information from subsequent visits.

The 3D modelling was done using the Autodesk 3ds Max to create models of both the machinery and the mill. Using basic objects and Boolean operations like extrusion and revolution, we were able to correctly identify the machinery in the windmill (Fig. 9).

\section{Applying textures}

In order to increase the quality of the virtual graphic reconstruction of the windmill, both for the operation of its machinery and the particle system used (a simulation of grains of wheat), different textures were used in the 3D model. This process involved applying a $2 \mathrm{D}$ image to a $3 \mathrm{D}$ object. A real object has a number of properties that characterise the material, including colour, roughness or brightness, depending on the light that it receives. The textures used in the study were derived by photo editing using Adobe Photoshop software. 


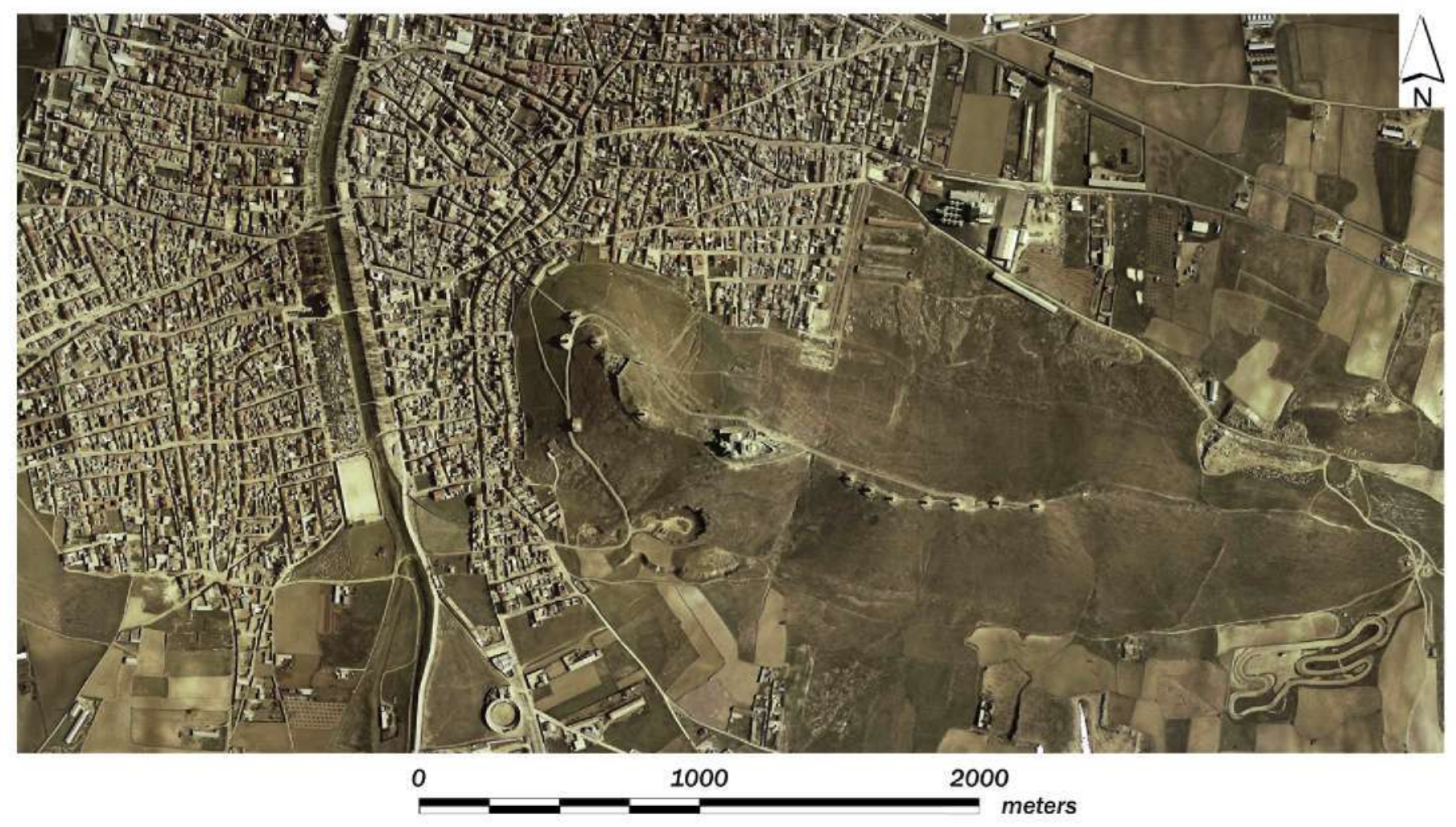

Fig. 6. Digital orthophotography obtained: Calderico Hill. Consuegra (Toledo).

\section{Lighting and shadows}

With proper use of lighting and shadows and by fitting the various parts of the mill to the actual conditions, we were able to give proper depth to the model. In this model, we used approximately 30 spotlights, including omnidirectional and directional lights. We also used 20 cameras to compose the animation model, where these were mounted on a spiral.

\section{$3 D$ animation and video editing}

For a computer animation of an image to appear realistic, there must be a sufficient number of frames per second to give the effect of continuity ( 25 frames per second).

The animation used to simulate the grinding process is known as a particle system. Particle systems are groups of objects that act as one and simulate elements, in our case wheat grains. Once created,
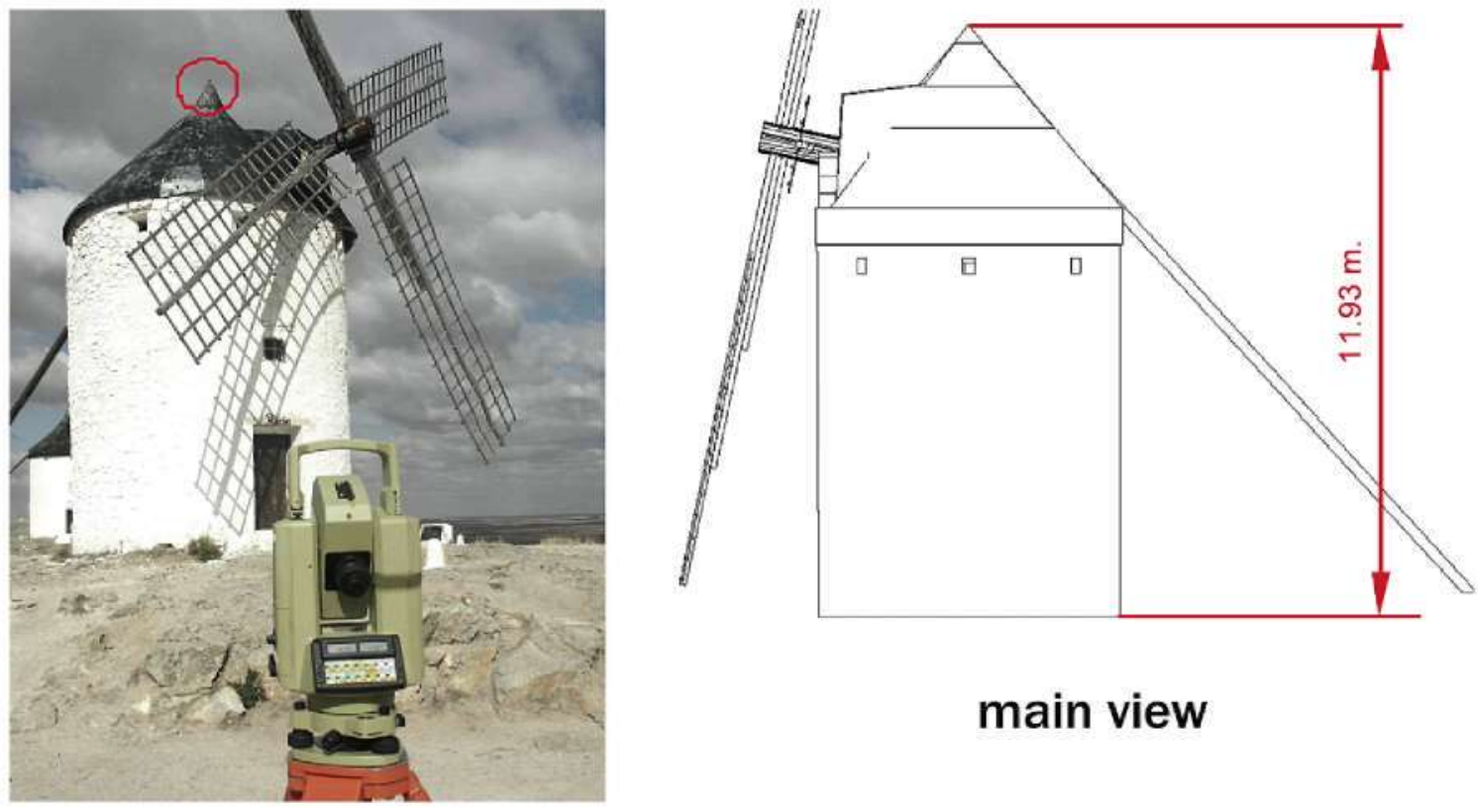

\section{main view}

Fig. 7. Survey data collection. 

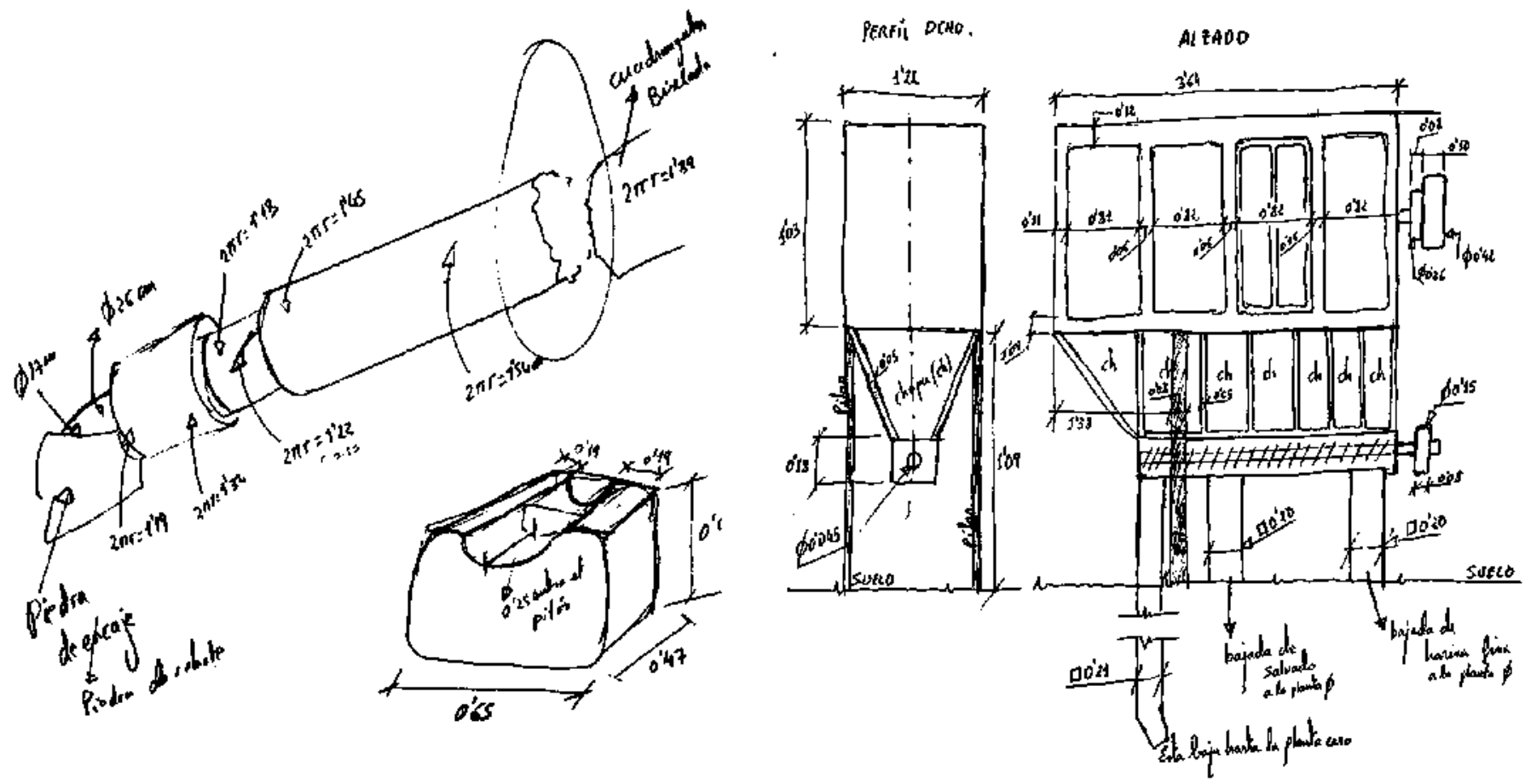

Fig. 8. Examples of drawings of different parts of the windmill. CAD Survey.

the particles must be configured to all of the system parameters, which are particle size, shape, density, direction, speed, volumetric variation, colour, gravity and surfaces of impact. We define as surfaces of impact (deflectors) the various pieces involved in the animation of a particle system. The 'tolva' and 'canaleja' are deflectors in the particle system created, or else otherwise the simulation of the collapse of the grains traverses these elements. Deflectors must define the impact force of particles, as well as chaos and friction.

In the rendering process, one can choose whether to render one time segment or the entire scene. We used audio files that were recorded during cereal milling in Campo de Criptana, which were later edited to improve audio quality and added to the video files for a higher level of realism.

\section{Results}

At first, the video files were in an AVl format, but they were subsequently converted into MPEG format for presentation using the video editing Adobe Premiere CS3 software http://www. madrimasd.org/blogs/vias_pecuarias/2009/06/26/120895.

The following two figures show some scenes the rendered 3D digital reconstiuction of the model windmill with materials, textures and lighting (Figs. 10 and 11).

\section{Discussion}

Examination of the intermediate and final results relating to the graphic and geo-visualisation study have confirmed the need for vittual reconstruction of the old windmills of Castilla-La Mancha. Pavlidis, Koutsoudis, Arnaoutoglou, Tsioukas, and Chamzas (2007) describe several methods for $3 \mathrm{D}$ digitising cultural heritage. The use of laser scanning was discarded because of poor accessibility and visibility of the mechanism of the windmill.

This information can support decision making in projects aimed at the conservation and landscape restoration. The main result of the research described in the present paper deals with a methodology
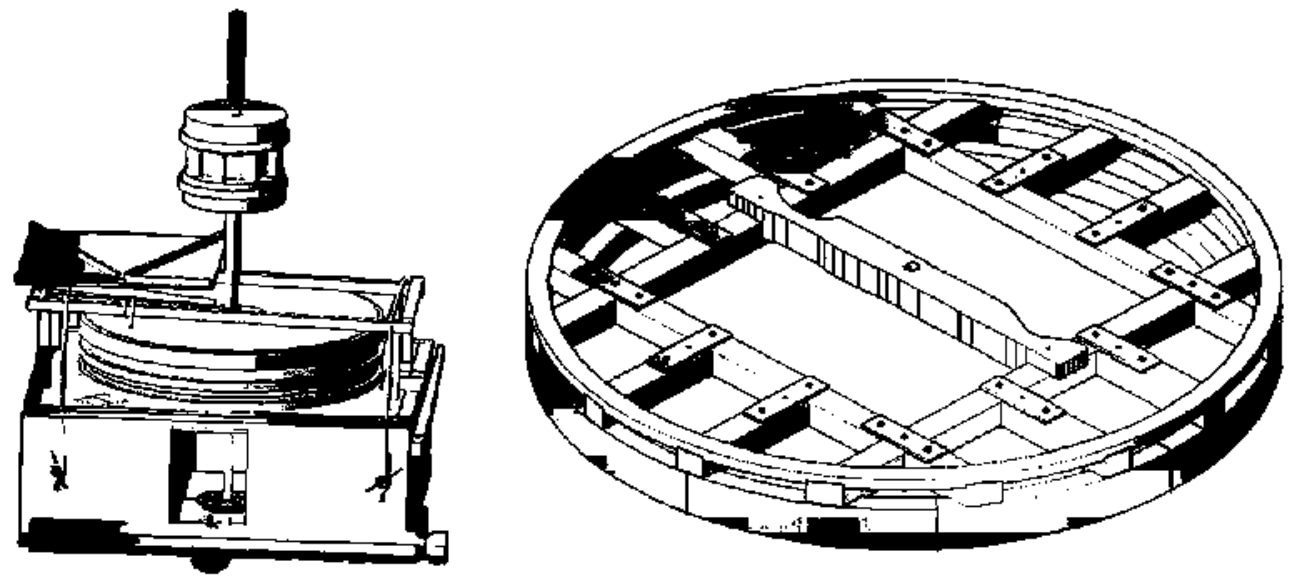

Fig. 9. 3D modelling of machinery elements of the windmill. 

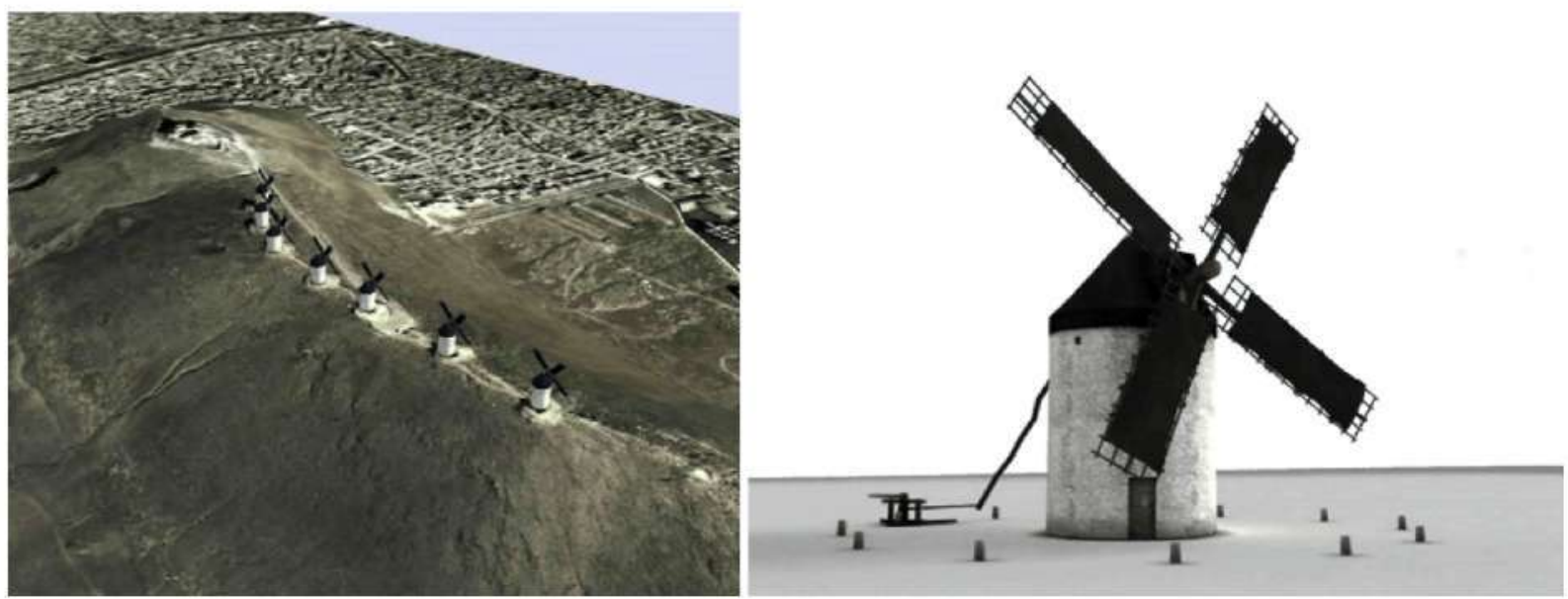

Fig. 10. DEM with superimposed digital orthophoto and windmill 3D model.
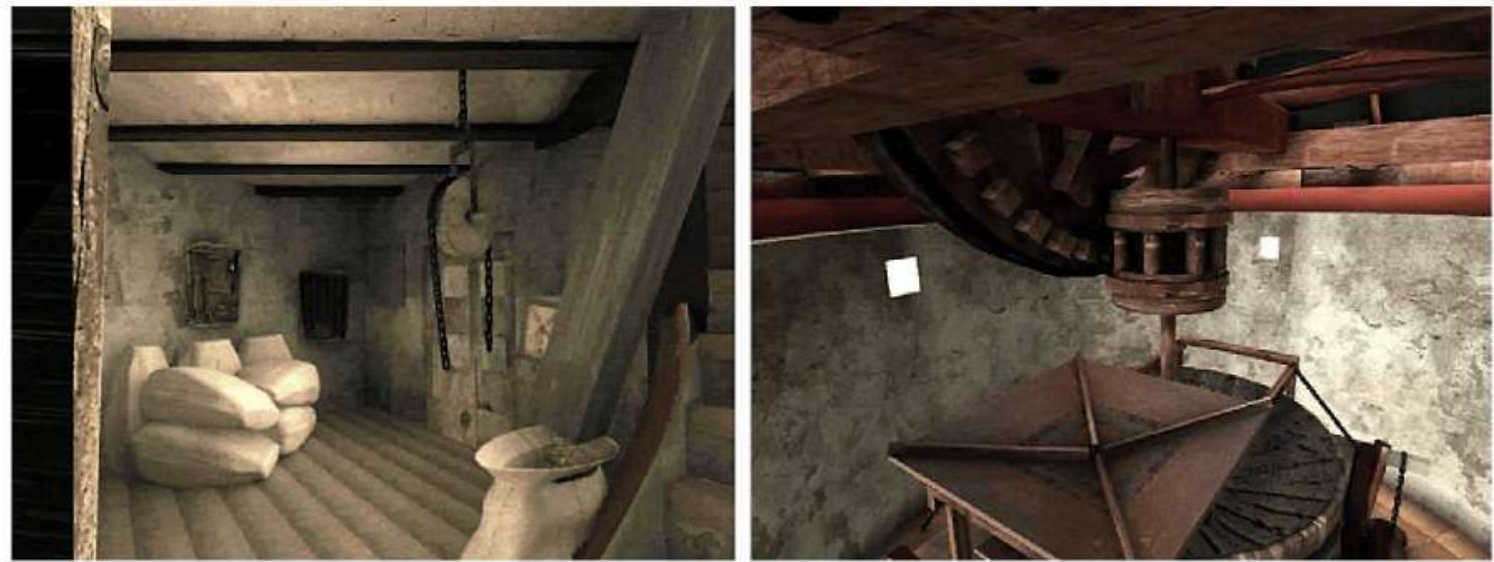

Fig. 11. On the left is the 'silo' or 'cuadra' and on to the right is the 'moledero'.

oriented to the information and operative management of old windmills in the landscape and cultural heritage (Mascari, Mautone, Moltedo, \& Salonia, 2009).

The direction and speed of the wind were calculated taking into account data from the automatic station No. 4-067 Madridejos $\left(03^{\circ} 32^{\prime} \mathrm{W}, 39^{\circ} 28^{\prime} \mathrm{N}\right)$. The location of the study area has a good rating (Rojas-Sola et al., 2006), as the annual average wind speed is $5 \mathrm{~m} / \mathrm{s}$ and the average power is $147 \mathrm{~W} / \mathrm{m}^{2}$.

According to data offered by the millers of Consuegra, $700 \mathrm{~kg}$ of grains were milled every day (12-14 h) with winds of $5 \mathrm{~m} / \mathrm{s}$. The power generated by the mill with winds of $5 \mathrm{~m} / \mathrm{s}$ was about $4320 \mathrm{~W}$ in $14 \mathrm{~h}$. The production rate would be around $50 \mathrm{~kg} / \mathrm{h}$.

\section{Future directions}

A Geographic Information System (GIS) that integrates all of the information from alphanumeric, cartographic, photographic and computer animations of windmills is needed to publicise the importance of our cultural heritage. Projects like the one conducted by the Spanish Association for the Conservation and Study of the Mills (http://www.molinosacem.com) are attempting to do this by creating a comprehensive database of windmills, waterwheels, mills and other mechanical devices (mills operated using conventional sources) in Spain. Excellence Andalusian has also begun a project called "The Historical Heritage of Andalusia Windmill" directed by Dr. Rojas-Sola. The group's participants have created an inventory of all the windmills of Andalusia as a first step towards the creation and implementation of a GIS.

According Vizzari (2010), a more extensive GIS participatory process oriented to more thorough involvement of local communities can improve the completeness of landscape data and the consistency of the whole evaluation (Cinderby \& Forrester, 2005; Gonzalez, 2002; King, 2002; Vajjhala, 2006; Wang, Yu, Cinderby, \& Forrester, 2008). By means of this process, local communities can contribute actively to the implementation and updating of GIS data and improving the evaluation of integrity and relevance of landscape elements.

We got into contact with the authorities of Castilla-La Mancha region and they are interested in integrating this project in the Geographic Service Site and in the Infrastructure of Space Date of this region. Our purpose is to let everybody know and divulge the performance and action of the old windmills as a cultural heritage http://ide.jccm.es/.

\section{Conclusions}

As a result of our investigation, we learnt of the rapid deterioration and abandonment of the cultural legacy of windmills. It is important to safeguard the agro-industrial heritage and technology assets that windmills represent.

This research developed a specific methodology to document and display the geographic areas where such singular constructions 
can be found. The techniques used are part of the engineering graphics and cartography fields.

The use of digital photogrammetry for the study of cultural heritage provides a 3D model of geographical space. After obtaining a DEM, important visual, terrain slope and iunoff studies can be performed (Pérez, 2008). A digital orthophoto that documents a unique place can act a tool when developing plans of action regarding that place. A graphic reconstruction of the windmill in La Mancha by computer graphics tools such as CAD, computer animation, photography and others, allowed us to create an accurate reconstruction of the mechanisms, machines or unique structures, which in turn allowed us to describe the technological and historical heritage of the object studied. An effective tool for geospatial studies is the use of video to disseminate research that integrates different techniques (Mills, Curtis, Kennedy, Kennedy, \& Edwards, 2010). The whole process of data collection and subsequent geovisualization are shown in the format avi assistant.

The ensuing publicity will expose the milling process and machinery of the windmill in La ManchaSpanish region to a wider audience and document its evolution.

\section{Appendix. Supplementary data}

Supplementary data associated with this article can be found, in the online version, at doj:10.1016/j.apgeog.2011.01.006.

\section{References}

Aguilar, ]. (1986). El viento, fuente de energía. Madrid, Alhambra.

Arias, $\mathrm{P}$, Ordonez, $\mathrm{C}_{4}$ Lorenzo, $\mathrm{H}_{4}$ Herraez, J \& Armesto, J. (2007). Low-cost documentation of traditional agro-industrial buildings by close-range photogrammetry. Building and Enviromment, 42, 1817-1827.

Arias, P. Ordóñez, C. Lorenzo, H., \& Herraez. J. (2006). Methods for documenting historical agro-industrial buildings: a comparative study and a simple photogrammetric method. Jounial of Cultural Heritage, 7, 350-354.

Cádiz. J. C., \& Ramos, J. (1984). La energía eólica: tecnología e historia. Madrid: Hermann Blume.

Camuñas-Rosell, J. L. (2000). El molino manchego. Toledo: Azacanes.

Caro-Baroja. J. (1952). Disertación sobre los molinos de viento. Cuaderno $2^{\circ}$. In Revista de Dialectología y Tradiciones Populares, Tomo ViII. Madrid, España: Bermejo. 213-366.

Catastro Marqués de la Ensenada. (1749-1756). Ittp://pares.mcu.es/Catastro.

Cinderby, S., \& Forrester, J. (2005). Facilitating the local governance of air pollution using GIS for participation. Appiied Geography, 25, 143-158.

Escribano. F. (2000). Los molinos de viento del Campo de Criptana a mediados del sigto XVIII. Ciudad Real: Ayuntamiento Campo de Criptana.

Fernández-layos. J. C. (1985). El molino de viento y su evolución tipológica en Consuegra (Toledo). Toledo.
Fernández, E., \& Fernández, C. (1997). Los molinos: Patrimonio industrial y cultural. Granada: Grupo Editorial Universitario.

Gonzalez, R. M. (2002). Joint learning with GIS: multj-actor resource management. Agricuitural Systems, 73(1), 99-111.

Herrero, T. R. (2005). Propuesta metodológica para el estudio de las vias pecuarias. Tesis Doctoral. Universidad Politécnica de Madrid. http://www.madrimasd.org/ blogs/vias_pecuarias!

Jiménez, J. (2001). Molinos de viento en Castifla-ia Mancina. Llanura, Giudad Real.

King. B. H. (2002). Towards a participatory GIS: evaluating case studies of participatory rural appraisal and GIS in the developing world. Cartography and Geographic Information Systems, 29(1), 43-52.

Konecny, G. (2000). Mapping from space, remote sensing for environmental data in Albania: a strategy for integrated management, Tirana, Albania. In M. F. Buchroitliner (Ed). NATO Science series, Vol. 72 (pp. 41-58). Dordrecht, The Netherlands: Kluwer Academic Publishers.

Mascari, G., Mautone, M., Moltedo, L., \& Salonia, P. (2009). Landscapes, heritage and culture. Journal of Cultural Heritage, io 1), 22-29.

McGlone, J. C. (2004). Manual of photogrammetry (5th edición). ASPRS (American Society for Photogrammetry and Remote Sensing).

Madoz, P. (1845). Diccionario geográfico-estadística-fístórico de Espania y sus posesiones de uitranar: Madrid, 441, 2 .

Martin. P., Llamas, J., Melero, A. Gomez-Garcia-Bermejo, J., \& Zalama, E. (2010). A practical approach to making accurate 3D layouts of interesting cultural heritage sites through digital models. Journal of Cuitural Heritage, 11, 1-9.

Mazuecos, R. (1971). Molinos de viento manchegos. Hombres, iugares y cosas de La Mancha, XXXII. Alcazar de San Juan.

Mills, J., Curtis, A., Kennedy, B., Kennedy. W., \& Edwards, J. (2010). Geospatial video for field data collection. Applied Geogropily, 30(4).

Pavlidis, G., Koutsoudis, A., Arnaoutoglou, F., Tsioukas, V., \& Chamzas, C. (2007). Methods for 3D digitization of cultural heritage, joumal of Cultural Heritage, 8 (1), 93-98.

Pérez. E. (2008), Estudio histórico-tecnológico y representación gráfica de ios molinos de viento de La Mancha en la España de los siglos XVI al XIX, mediante técnicas de Dibujo Asistido por Ordenador (DAO). Tesis Doctoral. Universidad Politécnica de Madrid. http:/loa.upm.es/1270/.

Pérez, E., Herrero, T. Gómez-Elvira, M. \& Rojas Sola, J. l. (2008). Assessment of precision in dems generated using automatic correlation. In VII jornadas Internacionales de Aplicaciones Geomáticas en ingeniería. Madrid: Escuela Técnica Superior de Ingenieros en Topografia, Geodesia y Cartografia. http:/foa.upm.es/ 2571 .

Rojas-Sola, J. l., \& Amezcua-Ogayar, J. M. (2005). Southern spanish windmills: technological aspects. Renewable Energy, 30, 1943-1953.

Rojas-5ola, J. l., Gómez-Elvira, M. A. \& Pérez, E. (2006). Computer-aided design and engineering: a study of windmills in la Mancha (Spain). Renewable Energy, 31, $1471-1482$

Sánchez-Ruiz, F. J. (1995). los molinos del corazón de la Mancha. Aicázar de San juan. Actas i Jontadas Nacionales Molinología (pp. 415-425). La Conuña, España. Vajjlala, 5. P. (2006). "Ground truthing" policy, using participatory map-making to connect citizens and decision makers. Resourtes, 162, 14-18.

Veco, M. (2010). A definition of cultural heritage: from the tangible to the intangible. Journal of Cultural Heritage. 11(3), 321-324.

Vizzari, M. (2010). Spatial modelling of potential landscape quality. Applied Geography, doi:10.1016fj.apgeog.2010.03.001.

Wang, X., Yu, Z., Cinderby, S., \& Forrester, J. (2008). Enhancing participation: experiences of participatory geographic information systems in Shanxi province. China. Applied Geography, 28(2), 96-109. 